\title{
ANDRAGOGY
}

\author{
UDC 37.091.39:374.7:37.014.54 \\ DOI 10.35433/pedagogy.1(96).2019.58-65
}

\author{
O. Ye. Antonova, \\ Doctor of Pedagogical Sciences, Professor \\ (Zhytomyr Ivan Franko State University) \\ olena.antonova2015@gmail.com \\ ORCID : $0 \odot \odot \odot-0 \odot \odot 2-3240-6297$
}

L. L. Familiarska,

$\mathrm{PhD}$ in Pedagogy, Teacher

(ME "Zhytomyr Regional Institute of Postgraduate Education" of Zhytomyr Regional

Council)

familyarskaya_la@ukr.net

ORCID : $0000-0002-5801-8057$

\section{STUDY OF THE DEVELOPMENT OF THE TEACHER'S INFORMATION AND COMMUNICATION MOBILITY WITHIN THE SYSTEM OF POSTGRADUATE EDUCATION}

\begin{abstract}
The article presents the results of the research of the essence, structure and features of the development of information and communication mobility of a teacher in the system of postgraduate education. The authors described the research process of information and communication mobility of a teacher, which involved a study of the current state of the issue, as well as an analysis of scientific literature together with the development of basic theoretical principles of the study. Generalization and systematization of information allowed the authors to determine the structural components of a teacher's information and communication mobility including criteria and indicators of its formation. The authors were further able to substantiate the conditions of its development in the educational environment of postgraduate education in the course and inter-course periods of professional development and advanced training.

The modular program of teacher training entitled "Development of information and communication mobility of the teacher in the educational environment of postgraduate education" is presented, together with the introduction of the method of its development in the educational environment of postgraduate education. In order to determine the level of formation of teacher's information and communication mobility, methods of evaluation, self-assessment, mutual evaluation and commentary are applied. The use of the developed diagnostic tools made it possible to evaluate the main components of the teacher's information and communication mobility: perception and analysis of new knowledge in the development of new professional activities (cognitivepersonal component), self-assessment and self-analysis of the effectiveness of activity and performance (evaluative-reflexive component), and the acquisition of connections in the process of the interaction of subjects of the educational process aimed at new skills and abilities utilization (social-activity component). With the help of methods of mathematical statistics (ranking, factor analysis, multidimensional dispersion analysis, parametric and nonparametric methods for comparing data using SPSS (ver. 13) computer software program) the effectiveness of the presented methodology is confirmed. The necessity of the interrelation of periodic advanced refresher training for the teacher along with their methodical work and active self-education in intercurricular period is substantiated.
\end{abstract}

Key words: postgraduate education, adaptation, information and communication mobility, development, environment, teacher.

Issue statement in general form. Globalization and European integration in all spheres of public life actualize the need to update and improve the content, methods and forms of the activity of a modern specialist. More specifically, within the terms of constant social motion, development and revolutionary change in the field of functionality and acquisition of information together with the massive use of newly designed communication technologies. All of these ideas are realized in the concept of mobility. A modern specialist should be resistant to adverse factors of activity, possess an ability to predict the development and sudden variability of the situation and respond quickly to changes, modifying the structure and sequence of 
actions. Furthermore, the ability to carry out duties in terms of constant lack of time without formidable performance and efficiency losses, as well as optimal decision making in unusual and extreme conditions, are inalienable.

The reorientation of the educational process into openness and mobility leads to changes in the professional activities of modern educators. The concept of "teacher's mobility" implies his / her personal ability to adapt to rapid changes in the ways of procedural interaction within the educational environment. This ensures the stability of his / her development and active professional position, as well as purposeful and conscious movement from position to position throughout his / her life. The more vivid a teacher's internal mobility is, the better he / she adapts to the new challenges, objectives and circumstances of his / her professional activity. This also causes the improvement of situational thinking and faster self-realization within social and professional hierarchy, making his / her pedagogical activity more diverse. According to Yu. S. Kopchak, L. V. Kopchak, Ya. Ya. Nikorak, R. Yuk, this particular characteristic quality is required for specialist's professional formation, development and successful activity in the modern socio-professional environment $[3 ; 8]$.

Therefore, the points of view of scientists indicate that the dominant meaning in the interpretation of the essence of different types of mobility is the idea of adaptability, flexibility and speed of response to changes in the terms and conditions of professional activity. However, beyond the scope of contemporary research lies the problem of the development of information and communication mobility as an adaptive ability of the individual, which needs to seek pedagogical innovations, aimed at the development of his/her professional and personal qualities.

Aim of the article is to characterize the results of the empirical study of the components of the information and communication mobility of a modern teacher and the conditions of their development in the environment of postgraduate education.

Analysis of recent research, the allocation of previously unsettled parts of the general issue. The concept of mobility as one of the characteristics of the social functioning of an individual in the modern world, including social groups, communities, personal development and humanity in general has been persisting in recent years. Modern researchers introduced the scientific concept of personal, social, communicative, labor and academic mobility. However, the active use of newly developed and advanced ICTs implies certain requirements the modern specialist should meet in order to be successful, such as mastering new skills and adapting them to information-based environments.

The above-mentioned research actualizes the study of the issues of the development of information and communicative mobility (ICM) of a teacher. This refers specifically to his / her adaptive ability to exercise effective interpersonal interaction in modern educational environment, as well as flexible application of information and communication technologies in professional work to solve educational tasks, objectives and issues.

Presentation of the main research material. The concept of ICM reflects the activity of the individual in any situation in the educational environment and is significant for various types of professional activity and social behavior of the specialist. These are characterized by flexibility within certain conditions of professional activity including ways of communication, cooperation, self-education and training, which are determined by technological and technical achievements of society. The essence of ICM is present not only in the indicators of knowledge and information / communication technology manipulation skills related to the informatization of education, but also in the ability of a modern teacher to behave him / herself appropriately in the digital environment using its capabilities in order to solve scientific and pedagogical tasks.

In the process of this scientific research, it was determined that the structure of information and communication mobility of the teacher consisted of an inter-system interdependence of three components: cognitive-personal, social-activity, and evaluative-reflexive. To identify the 
development of each of the structural components of the ICM, the following criteria was identified: awareness of the use of ICT in the educational process, understanding the need for mastering new ways of interaction in the educational environment [5; 7], communicativeness in the process of educational interaction of subjects in the educational environment $[1 ; 9]$, and reflexivity of activity efficiency [10]. Each criterion is characterized by certain indicators (online communication, self-understanding, readiness for self-development of information and communication mobility, variation of realization of creative potential, use of online technologies) that determine the degree of correspondence of the activities of the teacher to educational goals, norms and standards.

The development of a teacher's ICM was interpreted as his / her adaptation to computermediated interaction in the educational and professional environment, which characterizes the process of promotion of a specialist to a higher level of the ICM.

To study the level of formation of the components of a teacher's ICM and the subsequent indicators, a set of diagnostic tools was used to evaluate the data of the dependent variables of cognitive-personal, social-activity and evaluative-reflexive. 10 methods were processed in order to compose an author's questionnaire. During the selection of diagnostic tools the research was guided by the following inferences: the formed level of a teacher's ICM can be measures by its components, introduced criteria can help to evaluate these specific components, and that these criteria can be concretized and characterized by measurable indicators that can be observed, fixed, and determined.

In addition, a set of methods has been used in the research process that includes the following: observation, the tasks of which were a comprehensive study of the personality of the teacher in multifaceted behavioral manifestations that were utilized to determine the existing level of ICM; conversation with the teacher(s) (individual or group form) in order to obtain data on the motivation of the teacher's professional activities, individual characteristics, needs, abilities, etc; didactic testing to determine the level of formation of ICM including the completeness of possession of the necessary knowledge, skills and abilities; a questionnaire which revealed socio-demographic indicators of respondents (age, education, qualification category, pedagogical rank, experience of pedagogical work, place of residence) and their influence on the development of ICM, the formation of needs for improvement, conditions for their development, etc; content-analysis of messages from members of the online community; and content-analysis of the results of individual and group learning activities.

The study consisted of 180 teachers participating in advanced training courses. The general sample of respondents included 56 teachers with an accumulated experience of up to five years, 50 teachers with an accumulated experience of five to ten years, 43 teachers with an accumulated experience of ten to fifteen years, and finally 31 teachers with more than fifteen years of accumulated experience. Representativeness of the sample was achieved by a significant number of respondents who work in differing types of educational institutions (67 in rural schools, 84 in urban, 12 in boarding schools, 17 in vocational schools).

Determination of the level of ICM of teachers was conducted on the basis of the Zhytomyr Regional Institute of Postgraduate Pedagogical Education by a specially developed questionnaire "Study of the Level of Information and Communication Mobility (ICM) of a Teacher". This questionnaire allowed respondents to reveal some social information about themselves and their level of formation of ICM's components (cognitive-personal, evaluativereflexive, social-activity) together with the peculiarities of their behavioral adaptation to the use of computer facilities and online technologies, etc.

Additionally, the methodology of V. G. Maralova "Detection of the teacher's ability to selfdevelopment" [4] and a self-attitude questionnaire created (OS) by V. V. Stolin, S. R. Panteleyev were utilized [6]. This revealed the personal attitude of teachers to the identified issue, their needs for improvement and the conditions for the development of ICM. 
Results of diagnostics were included in the computer database program SPSS, which simplified their subsequent statistical processing and analysis.

The obtained data revealed that in general teachers have high motivation and determination to master the new aspects of interaction with the use of modern educational environment and ICT (information and communication technologies). Even teachers with over 20 years of experience positively responded to this process and expressed a desire to learn new ways of interaction. This category of educators noted that trends in the development of mobile computing devices and technologies necessitate the adaptation of their use in the process of interaction with students and the need for training for those professionals whose work experience exceeds 15 years. They also emphasized the fact that adaptation has became an integral part of life's journey for the modern teacher due to innovations in technology, the instability of socio-economic conditions, personal changes and so on.

To confirm the theoretical model of ICM, a factor analysis of the statistical data was conducted using SPSS 13.0 software. The matrix of inverse components of the constructed factor model contained the content of each selected particular factor. The Z-value of factor loads, which is less than 0.1 , was omitted by SPSS to simplify the analysis of the data obtained. As a result, the ICM model was formed. It consisted of three factors (cognitive-personal (IStudy), social-activity (I-Interact), and evaluative-reflexive (I-Analyze)). This fully confirmed the defined structural components of the preliminary theoretical model.

It should be noted that the data aggregation (ANOVA) of the conducted dispersion analysis revealed the closest connections between the factor indicators within each group, as well as between themselves (factors). This made it possible to further determine the actual aspects of the development of the teacher's ICM and was reflected in the study's program of development of information and communication mobility of a teacher in the system of postgraduate education.

The generalized actual material obtained and processed during the research allowed for the allocation of three levels of development of the teacher's ICM depending on the value of the range factor and its coefficient (the degree of display of the indicators): low (intuitivereproductive), average (constructive-search), and high (creative-productive), presented in Table 1.

Table 1

Generalized indicators of the development of the components of ICM of the teacher, (\%)

\begin{tabular}{|l|l|l|l|l|}
\hline $\begin{array}{l}\text { Development } \\
\text { components } \\
\text { (factors) }\end{array}$ & $\begin{array}{l}\text { Social-Activity } \\
\text { (I-Interact) } \%\end{array}$ & $\begin{array}{l}\text { Evaluative- } \\
\text { reflexive } \\
\text { (I-Analyze) } \\
\%\end{array}$ & $\begin{array}{l}\text { Social-Activity } \\
\text { (I-Study) } \\
\%\end{array}$ & $\begin{array}{l}\text { Total } \\
\text { Development } \\
\text { Indicator } \\
\%\end{array}$ \\
\hline Low & 51 & 51 & 52 & 51,3 \\
\hline Medium & 24,5 & 26 & 26,5 & 25,6 \\
\hline High & 24,5 & 23 & 21,5 & 23,1 \\
\hline Total & 100,0 & 100,0 & 100,0 & 100,0 \\
\hline
\end{tabular}

Indicators of all structural components were distributed by levels almost equally, from low to high. It should be noted that the low level (intuitive-reproductive, displaying $51 \%, 51 \%$, and $52 \%$ respective rate) was revealed to be dominant among the indicators of the structural components of the ICM. This indicated gaps in the following areas: knowledge of the teachers regarding the theoretical foundations of the use of the true potential of ICT (cognitive-personal component), self-examination skills including teacher quality and efficient self-assessment concerning information and communication interaction in the educational environment (evaluative-reflexive component) and possession of ways to self-organize educational interaction with the use of modern means of communication (social-activity component). 
According to the selected levels of ICM formation, teachers' self-evaluation was conducted. More than a half of respondents $(56,44 \%$ ) defined their level as high on a ten-point scale (selfassessment $-10,9,8,7$ points), one third (37,2\%) gave themselves a medium mark (selfassessment $-6,5,4,3$ points), 6,3 \% (self-assessment $-2,1,0$ points) identified themselves as being on a low level (pic. 1).

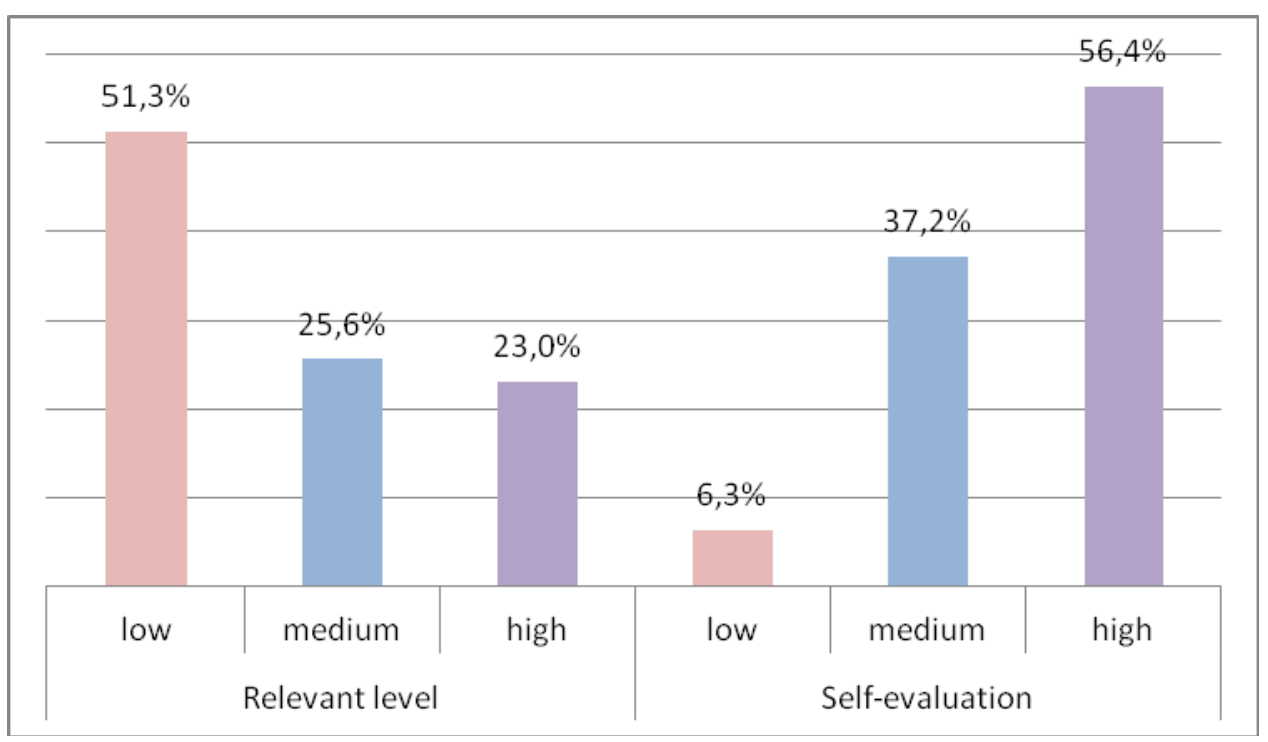

\section{Pic. 1. Comparison of the indicators of the current ICM level and the results of teachers' self-assessment (ICM)}

Differences between the indicators obtained in the process of teachers' self-evaluation and diagnostics were revealed. It was determined that the reason for the discrepancy was an imbalance between the level of social-activity component $(81,6 \%$ of respondents have medium and high level) and the level of social phenomena combined with the level of cognitive-personal component $(37,1 \%$ of participants have medium and high level). The social activity component is formed under the influence of socio-economic processes, with the social phenomena / cognitive-personal component being formed exclusively under the influence of education activities and the process of self-development.

An analysis of the results lends to the assertion that teachers understand the role of modern technology in educational activities sufficiently, but still continue to perform their usual role as repeaters (plain reproduction) of ready-made knowledge. Many experienced teachers are not familiar with or have insufficient knowledge about the new roles of a teacher. These new roles include teachers who can effectively work with growing volumes of information in the media educational environment and self-organize in it using the capabilities and opportunities given by the electronic digital data-based environment.

The data obtained during the statistical processing and interpretation allowed the study to highlight crucial factors in the development of a teacher's ICM, depending on age and qualification, seniority of professional activity, position and territorial affiliation, etc. These were taken into account when developing the content of the program "Development of information and communication mobility of a teacher". The aim of the ICM development program is to make qualitative changes in the teacher's professional characteristics that are necessary for the implementation of computer technology-mediated learning activities in the educational environment. In particular, for the formation of cooperative activities and training in the educational electronic digital data-based environment.

To implement the program of development of teachers' ICM, the total experimental sample (453 respondents) was divided into experimental (229 teachers) and control (224 participants) 
groups. The training was carried out in the course (6 hours of classroom work and 30 hours of independent non-auditing work) and inter-curricular period of teacher training (108 hours selfstudy of educational modules with methodological support), which was important in the process of his / her continuous growth and development. The program introduced a set of modern teaching methods (case method, training, mutual evaluation, mutual certification, master class, discussion, online conference), the use of e-learning opportunities and the implementation of individual learning strategies.

The objectives of the module program (144 hours) were aimed at the development of the adaptive ability of the individual and the interaction between the subjects in the educational environment. This included two parts. Firstly, the implementation of the course (36 hours), which included familiarization, systematization and mastery of forms, methods of pedagogical activity in the educational environment for purposeful use of means of communication and ways of their integration with traditional training. Secondly, inter-course teacher training (108 hours), which included designing the impact of their own achievements on professional activities, contributing to the adaptation of the professional interests and needs of the teacher to the purpose of the activity, the formation of an ICT-supported professional activities, and the development and rationalization of the individual-optimal style of modern activity.

The method of implementation of the teachers' ICM development program presupposed the principles of systemic growth of the individual. This ensured the amplification of all indicators of ICM and the continuity of stages and objectives, from self-understanding to selfmanagement. Furthermore, this made certain the active integration of the results with the professional activities of the educators and the transition from "closed" communication to "open" (subject-subjectivity relations) in order to form a creative position. This created an environment conducive to the self-examination and self-assessment of a teacher, including analytical awareness of his/her own behavior. This gave him/her an opportunity to seek alternative options of modern communication, its reflexivity and to ensure understanding of the strategy of personal change(s).

The conducted experiment showed positive dynamics in the indicators of ICM levels within the experimental and control groups (pic. 2).

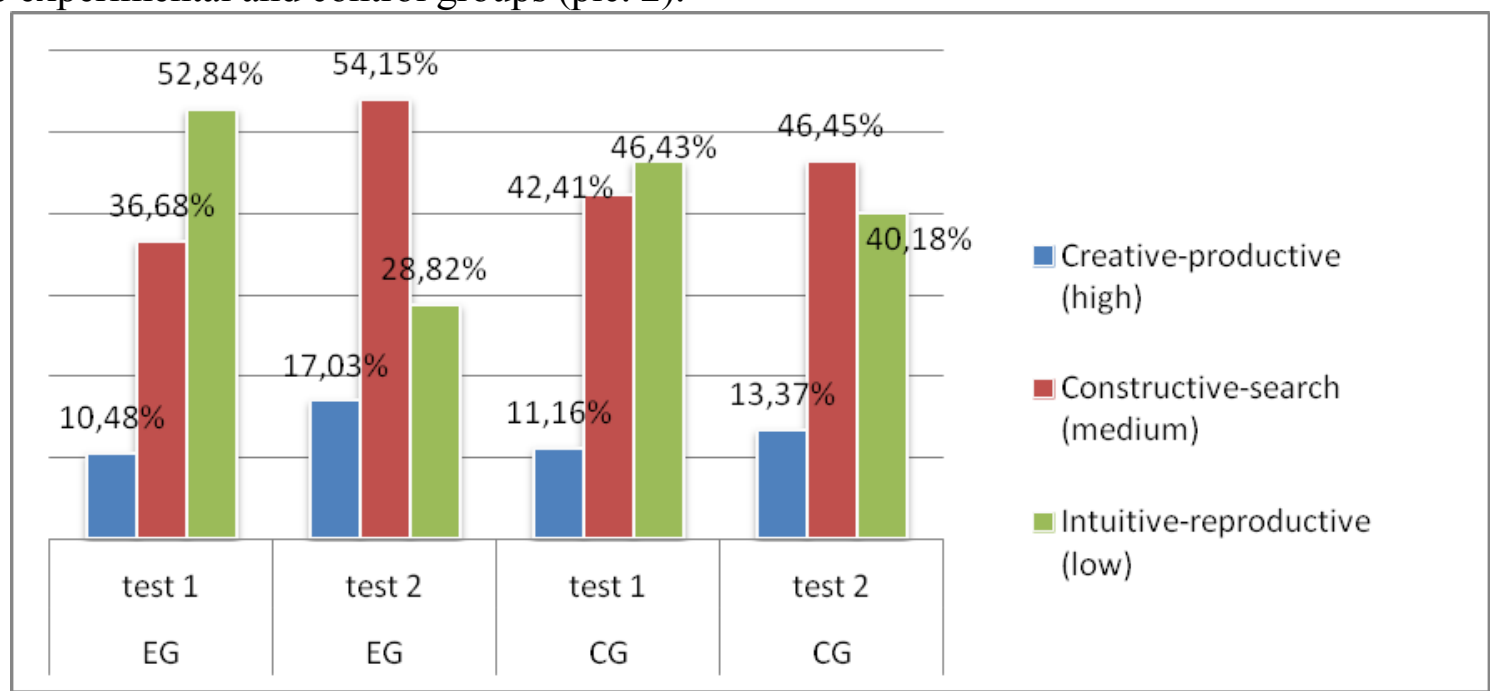

Pic. 2. Changes in the overall rate of development of ICM in the control and experimental groups $(\%)$

The results of the comparative analysis of empirical data revealed significant differences in the quantitative and qualitative indicators of teachers' ICM. In experimental (EG) and control (CG) groups, the total number of teachers with high level of ICM (EG - from 10,48\% to $17,03 \%$ and $C G$ - from $11,16 \%$ to $13,39 \%$ ), medium level of ICM (EG - from $36,68 \%$ to 
$54,15 \%$ and CG - from $42,41 \%$ to $46,43 \%$ ) increased. Respectively, the rate of low-level ICM teachers decreased in all experimental groups (EG - from $52,84 \%$ to $28,82 \%$ and $\mathrm{CG}$ - from $46,43 \%$ to $40,18 \%$ ).

It should be mentioned that both experimental groups (EG and $C G)$ were characterized by an increase in the indicator of high and medium levels of the social-activity component with the marker "readiness for self-development ICM" (by 9,6\%). This shows the positive attitude of respondents to the use of online technologies in professional development activities and motivation to succeed. The growth of indicators of high and medium levels of the evaluativereflexive component in the experimental group with the markers "use of online technologies" (by $12.6 \%$ ) and "variation of creative potential" (by 13.5\%) indicates that the involvement of teachers in professional interaction within the prepared educational environment provides means and conditions for the realization of creative potential (goo.gl/ra1SRe,goo.gl $/ \mathrm{kFBbH} 8$ ). Comparing their own point of view with the thoughts of other participants enables an individual (a teacher) to perceive and understand the attitude of respondents involved in the educational process, which resulted in interaction, information exchange and pedagogical communication. In EG and CG, a slight decrease in the indicator of the cognitive-personal component of "selfunderstanding" (3.1\%) has been identified. It is explained by the objective need for a teacher to invest substantial work in changing his/her professional approaches towards organizing educational interaction, as well as raising his/her own level of critical attitude towards professional "self" together with the effectiveness of organization of modern information interaction and pedagogical communication.

The processed empirical data confirmed the effectiveness of the work carried out and became the basis for the development of scientific and methodological materials on the issue of activation of the development of teacher's ICM in the system of postgraduate education.

Conclusions and further research perspectives. Thus, the process of carrying out the experiment, data processing and its further analysis using the methods of mathematical statistics (SPSS 13.0 software) was performed. This allowed the study to confirm the determined structural components (cognitive-personality, evaluative-reflexive, social-activity) of the theoretical model of teachers' ICM and to identify the peculiarities of their development.

Approbation of the program was carried out taking into account the results of the research of the peculiarities of the development of the teacher's ICM of respondents of different age and qualification categories, professional experience, position and territorial affiliation. It contributed to the essential development of the components of the teacher's ICM.

According to the results of experimental work, positive changes were found and identified in all components of the teacher's ICM. Thus, the effective implementation of the model of development of the teacher's ICM becomes possible. This is achieved with the close interconnection of periodic course improvement of teachers' qualifications with their methodical work and active self-education in the intercultural period, sticking to certain conditions, approaches and principles.

This research does not exhaust the complex set of scientific and practical problems related to the development of information and communication mobility of a teacher in the system of postgraduate education. Specific areas of further research include an in-depth study of the manifestations of individual peculiarities of the development of a teacher's ICM at various stages of professional development.

\section{REFERENCES (TRANSLATED \& TRANSLITERATED)}

1. Voronovska, L.P. (2015). Komunikatyvna mobilnist, yak skladova chastyna profesiinoi mobilnosti [Communicative mobility as part of professional mobility]. Proceedings of the 11th International Conference: Mizhnarodna naukovo-praktychna konferentsiia "Osvita i nauka bez kordoniv" - The 11th International Conference "Education and Science without Borders". (pp. 5-8). Peremyshl: Vydavnycztvo Sp.z.o.o. "Nauka i doslidzhennia" [in Ukrainian]. 
2. Grytskova, N.V. (2011). Osoblyvosti sotsialno-profesinoi mobilnosti vchytelia v umovakh suchasnoi serednioi shkoly [Features of social-professional mobility of a teacher in modern high school]. Naukovyi visnyk Donbasu - Academic Bulletin of Donbas, 1 . Retrieved from http://nbuv.gov.ua/UJRN/nvd_2011_1_6 [in Ukrainian].

3. Kopchak, Yu.S., Kopchak L.V. \& Nykorak, Ya.Ya. (2016). Pedagogichna mobilnist u dobu zmin ta transformatsii [Pedagogical mobility at the age of change and transformation]. Girska shkola ukrainskykh Karpat - Mountain School of Ukrainian Carpathians, 15, (pp. 49-53). DOI: 10.15330/msuc.2016.15.49-53 [in Ukrainian].

4. Maralov, V.G. (2004). Osnovy samopoznaniia $i$ samorazvitiia [Basics of self-knowledge and selfdevelopment]. Moskva: Akademiia [in Russian].

5. Sergeieva, T.B. (2015). Lichnostnaia i professionalnaia mobilnost: problema sopriazhennosti [Personal and professional mobility: the problem of contingency]. Obrazovaniie i nauka-Education and Science, 8 (127), 81-96. DOI: 10.17853/1994-5639-2015-7-81-96 [in Russian].

6. Stolin, V.V. (1983). Samosoznanie lichnosti [Self identity]. Moskva: Pedagogika [in Russian].

7. Mell, P., Grance T. (2011). The NIST Definition of Cloud Computing. National Institute of Standards and Technology (NIST), Vers. 15. DOI: 10.6028/NIST.SP.800-145 [in English].

8. Romiţă Iucu, Ion-Ovidiu Pânişoară. (2011). The Professional Mobility of Teachers - new tendencies in the global society. Procedia-Social and Behavioral Sciences, 11, 251-255. DOI: org/10.1016/j.sbspro.2011.01.071. [in English].

9. Valeeva, Roza A. \& Lyudmila Amirova A. (2016). The Development of Professional Mobility of Teachers in Supplemental Education System. International Journal of Environmental and Science Education, 11 (9): 2265-2274. DOI: 10.12973/ijese.2016.603a. [in English].

10. Yvonne, Albrecht. (2019). The Contemporaneity of Grounded Theory: Data and Emotional Reflexivity. Sociological Focus, 52. DOI: 10.1080/00380237.2018.1544516.

Received: December 27, 2018 Accepted: March 06, 2019

\section{Дослідження розвитку інформаційно-комунікаційної мобільності педагога в післядипломній освіті.}

У статті представлено результати дослідження сутності, структури та особливостей розвитку інформаційно-комунікаційної мобільності педагога у системі післядипломної освіти. Авторами охарактеризовано прочес дослідження розвитку інформаційно-комунікаиійної мобільності педагога, щзо передбачало вивчення сучасного стану проблеми, аналіз наукової літератури, розроблення основних теоретичних положень дослідження. Узагальнення та систематизація інформації дозволило визначити структурні компоненти інформаційно-комунікаційної мобільності педагога, критерії та показники рівнів ї̈ сформованості, обтрунтувати умови ії розвитку в освітньому середовищі післядипломної освіти в курсовий та міжкурсовий періоди підвищення кваліфікащії.

Представлено модульну програму навчання вчителів у післядипломній освіті "Розвиток інформаційнокомунікаційної мобільності педагога в освітньому середовищі післядипломної освіти", методику ї̈ розвитку в освітньому середовищі післядипломної освіти. Для визначення рівня сформованості у педагогів інформаційно-комунікаційної мобільності застосовано методи оцінки, самооцінки, взаємооцінки, взаємокоментування. Використання розробленого діагностичного інструментарію дозволило здійснити очзінювання основних компонентів інформаційно-комунікаційної мобільності педагога: сприйняття та аналізу нових знань щзоо освоєння нових видів професійної діяльності (когнітивно-особистісний компонент), самооцінку ефективності діяльності, самоаналіз результативності діяльності (очінно-рефлексивний компонент), набуття зв'язків у процесі взаємодії суб'єктів освітнього процесу, зокрема, з метою навчання (соціально-діяльнісний компонент). $3 a$ допомогою методів математичної статистики (ранжування, факторний аналіз, багатомірний дисперсійний аналіз, параметричні та непараметричні методи порівняння даних з використанням комп 'ютерної програми SPSS - версія 13) підтверджено ефективність пропонованої методики.

Обгрунтовано необхідність взаємозв'язку періодичного курсового підвищення кваліфікації педагогів з їх методичною роботою й активною самоосвітою в міжкурсовий період.

Ключові слова: післядипломна освіта, адаптування, інформаційно-комунікаційна мобільність, розвиток, середовище, педагог. 